\title{
Shareholder rights, shareholder voting, and corporate performance
}

\author{
Chris Mallin • Andrea Melis
}

Published online: 11 May 2010

(C) Springer Science+Business Media, LLC. 2010

\section{Introduction}

The areas of shareholder rights and shareholder voting are fundamental features of a sound corporate governance system. The Organisation for Economic Co-Operation and Development (OECD) Principles of Corporate Governance (2004) state that 'the corporate governance framework should protect and facilitate the exercise of shareholders' rights' and amongst these shareholder rights are the right to relevant, timely and regular information about the company; the right to participate and vote in shareholder meetings; the right to elect and remove members of the board; and the right to share in the company's profits. Shareholders are the providers of risk capital and as such they need to be able to protect their investment by ensuring that a competent board is in place to manage the company and to ensure that effective strategies are in place for the company's overall corporate performance and longterm sustainability.

The International Corporate Governance Network (ICGN) issued its revised Global Corporate Governance Principles (2009a) and one of the principles, Principle 8, relates to Shareholder Rights. Principle 8 includes accountability of the board to shareholders; shareholder protection whereby boards 'treat all the company's shareholders equitably and should respect and not prejudice the rights of all investors. Boards should do their utmost to enable shareholders to exercise their rights, especially the right to vote, and should not impose unnecessary hurdles'; voting-related rights whereby the exercise of ownership rights by all shareholders should be facilitated; and shareholder rights of action such that

C. Mallin $(\bowtie)$

Birmingham, UK

e-mail: c.a.mallin@bham.ac.uk

\section{A. Melis}

Cagliari, Italy

e-mail: melisa@unica.it 
shareholders who are treated inequitably have rights of redress, for example, minority shareholders who find themselves subject to abusive or oppressive conduct should be able to find redress for this.

The shareholders' rights outlined above are clearly seen as fundamental to the shareholder-company relationship. Directors are in a position of trust and should manage the company in such a way as to generate long term sustainable value whilst also taking into consideration their relationships with wider stakeholder groups including employees, customers, suppliers and the wider community on which their activities have an impact. Shareholders' rights include, as we have seen above, shareholder voting which is an important tool as it can be used to elect directors, to approve the annual report and accounts and so on. In the context of shareholders' voting at general meetings in the Netherlands, de Jong et al. (2006) describe the various areas that may be decided upon at a company's general meeting. These include adoption of the annual accounts by the general meeting (which may, depending on the country, imply a discharge of management board members and supervisory board members from liability for the performance of their duties); distribution of profits; issue of shares and pre-emptive rights; share repurchase; amendment to articles of association; reduction of share capital; appointment of external accountant/auditor; remuneration of board members; appointment and dismissal of board members; and takeover defences.

Gillan and Starks (2007) place shareholder activism on a continuum of reactions that unhappy shareholders can give to corporate governance concerns. On the one side, shareholders can sell their shares (i.e., vote with their feet), while at the other extreme of the continuum is the market for corporate control, where investors start takeovers to bring about corporate changes. The role of shareholder activism arises when shareholders decide to hold their shares and try to induce changes within the company without a change in its control. These investors may then press for corporate reforms by negotiating with senior management (or the board of directors) behind the scenes, or-especially when the former is unresponsive-by submitting proposals for shareholder vote.

The shareholder vote is increasingly considered as one of the most powerful means that institutional investors have to engage with the boards of directors of their investee companies (see e.g., Bebchuk 2005; Mallin, this issue). Previous empirical studies found that shareholders do exert pressures on boards of directors even when their vote at the shareholders' meeting is not legally binding, because proposals that win a majority vote end up being implemented by the board of directors in many cases (Bizjak and Marquette 1998; Martin and Thomas 1999; Thomas and Cotter 2007; Ferri and Sandino 2009; Ertimur et al. 2010), with relevant spillover effects even on non-target companies (Ferri and Sandino 2009). Boards of directors that choose to ignore the shareholder vote have been shown to draw negative press and receive downgrades by governance rating firms. In the US such directors become less likely to be re-elected and more likely to lose other directorships (Ertimur et al. 2010). Hence shareholder proposals appear to have an emerging role in reducing agency costs by increasing director responsiveness to shareholder concerns (Thomas and Cotter 2007). 
As well as shareholder voting, institutional shareholders have other means at their disposal to engage with the board. These include constructive dialogue with companies, usually in the form of regular face-to-face meetings but also via other means such as telephone conversations (Logsdon and Van Buren III 2009). For example, Brav et al. (2008) report that US-based hedge fund activists adopt a wide variety of tactics to pursue their aims, from friendly interactions with senior management to being openly confrontational with target boards of directors. Melis et al. (2010) provide evidence that minority shareholders can successfully exert an influence on executive remuneration design when they are able to appoint a director to the board.

Various studies have shown that there is a link between shareholder rights and corporate performance, in the sense that being able to exercise shareholder voting rights, or engage with companies via dialogue or other means such as focus lists, has a positive effect on corporate performance. Gompers et al. (2003) examined the ways in which shareholder rights vary across firms. They constructed a 'Governance Index' to proxy for the level of shareholder rights in approximately 1,500 large firms during the 1990s. An investment strategy that bought firms in the lowest decile of the index (strongest rights) and sold firms in the highest decile of the index (weakest rights) would have earned abnormal returns of 8.5 percent per year during the sample period. They found that firms with stronger shareholder rights had higher firm value, higher profits, higher sales growth, lower capital expenditures, and made fewer corporate acquisitions.

In situations where directors are not responsive to dialogue with institutional shareholders, then investor activism may include putting the company on a focus list such as those operated by the California Public Employees Retirement System (CalPERS). Corporate performance is often shown to improve after such engagement, for example, studies such as those carried out by Nesbitt (1994) have reported positive long-term stock price returns to firms targeted by CalPERS. Nesbitt's later studies show similar findings. Brav et al. (2008) describe various objectives of hedge funds' activism (e.g., changes to company capital structure, altering company business strategy, seeking a sale of the target company, and making improvements to its corporate governance) and found that target companies experience increases in returns on assets, operating profit margins, and total payout yields.

The effectiveness of engagement is also highlighted by the study carried out by Becht et al. (2009). The researchers were given unlimited access to Hermes' resources such as reports, transcripts of telephone conversations and so on which documented the work with the companies in which Hermes' UK Focus Fund invested over the 1998-2004. They reviewed all forms of public and private engagement with 41 companies. They found that when the engagement objectives led to actual outcomes, there were economically large and statistically significant positive abnormal returns around the announcement date. On the basis of their findings they concluded that shareholder activism can produce corporate governance changes that generate significant returns for shareholders.

Finally, the global financial crisis has once again highlighted the importance of corporate governance in restoring trust in global capital markets. The ICGN (2009b) 
statement emphasized '...securing and maintaining the rights of shareholders and developing the transparency needed for them to exercise these rights in a responsible, informed, and considered way'. Ultimately it is only with shareholders exercising their protected rights and engaging with companies that overall risks can be mitigated and long term sustainable corporate performance achieved.

\section{The University of Cagliari conference}

The University of Cagliari was host to an international corporate governance forum on emerging issues in shareholder rights, shareholder voting and corporate performance, together with related theoretical developments and empirical analysis. The international conference took place in March 2008 and was jointly organised by the University of Amsterdam Center for Law and Economics, the Department of Ricerche aziendali of the University of Cagliari, and the Law and Business Program of the Vanderbilt University School of Law, in collaboration with the European Corporate Governance Institute and this Journal. The two-day conference, which featured leading scholars from Europe and the United States, generated a constructive and informative debate about the relation between shareholder voting, shareholder rights and firms' characteristics and performance. The conference also gave the opportunity to launch a special issue on this topic, which led to the selection of the following four papers.

The paper by Chris Mallin 'Institutional Investors: The Vote as a Tool of Governance' provides an overview of the growth of institutional investor influence and the various expectations of the role of institutional investors in corporate governance that come from various codes, guidelines, and the government. The vote is increasingly considered as one of the most powerful means that institutional investors have at their disposal to engage with their investee companies and try to help ensure that the latter have an appropriate corporate governance structure and that they operate according to corporate governance best practice. In particular, this paper contains an in-depth examination of the voting policies and actions of two large UK-based institutional investors (Hermes and Aviva Investors), which are active in corporate governance. Mallin finds that most times institutional investors vote in support of incumbent management, however there are certain resolutions which prove to be more contentious, such as those relating to the appointment/reelection of corporate directors and board composition; board remuneration packages and incentive schemes; and strategic issues that are likely to have an impact on shareholder rights and/or ownership interests. The paper also provides an analysis of the resolutions which occur most frequently together with the average levels of dissent on such issues in thirteen European countries. The barriers to voting that may arise are also examined; such barriers include control enhancing mechanisms which are prevalent in many of the European countries considered.

The paper by Joseph McCahery and Erik Vermeulen 'Private Equity Regulation: A Comparative Analysis' evaluates whether existing contractual arrangements and industry standards are sufficient for dealing with the problems generated by private equity and buyout funds given their rapid growth. They identify 
governance problems and risks and discuss the diverse range and effectiveness of different regulatory measures in Canada, Germany, the Netherlands, and the UK. They also consider whether co-regulation might be an attractive measure to underpin industry body monitoring and compliance measures and conclude that a system of co-regulation may result in effective compliance by providing an appropriate threat in those cases where self-regulation fails. Regarding regulatory measures in relation to limiting market abuse by fund managers and facilitating growth and innovation, they conclude that there is a well-developed framework of corporate and securities law that is appropriate for dealing with private equity transactions and parties to these transactions. European policymakers have focused on implementing laws recently on the regulation of takeovers, disclosure and the prohibition of market abuse and insider trading that will improve the procedures for takeovers and buyouts while protecting the interests of investors and promoting confidence in the market.

The paper by Sudi Sudarsanam and Tim Broadhurst 'Corporate Governance Convergence in Germany Through Shareholder Activism: Impact of the Deutsche Boerse Bid for the London Stock Exchange' marks the emergence of the AngloAmerican style shareholder rights movement in a country such as Germany, in which only limited power to the shareholders of corporations is given. The authors provide case study evidence about the shareholder revolt initiated by a small activist shareholder. This evidence provides a useful insight into the processes used by relatively small investors to exercise their rights to thwart a takeover offer and topple some powerful corporate executives. In particular, the Deutsche Boerse case illustrates how a single issue such as the strategic logic or the value creation potential of a takeover bid can rapidly spiral to become a wider campaign over deeply rooted governance concerns at targeted companies. Through event study analysis Sudarsanam and Broadhurst reveal how the stock market reacted to the activists' intervention. Last but not least, the case sheds light on the importance of communication between senior management and shareholders, especially when corporate decisions of great strategic importance, such as a takeover, are being implemented.

Finally the paper by Caspar Rose 'The New European Rights DirectiveRemoving Barriers and Creating Opportunities for More Shareholder Activism and Democracy' analyses the nature of shareholder activism in the light of the new European Union Directive, by arguing that this Directive is only the first step in a legal process that is expected to substantially increase shareholder rights in coming years. The paper also illustrates the notion of 'shareholder democracy' that is crucially dependent on active minority shareholders and argues that the notion of shareholder democracy may serve as guidance for how future legislation should be designed. Rose acknowledges that not all shareholders are long-term oriented, and questions whether short-term investors should be given the same rights as those shareholders who are devoted to the long-term value creation that also benefits the firm's stakeholders as well as society.

The publication of these papers is aimed at stimulating debate on the important topics of shareholder rights, shareholder voting and corporate performance which are fundamental to an effective corporate governance system. 


\section{References}

Bebchuk, L. (2005). The case for increasing shareholder power. Harvard Law Review, 118(3), 835-914.

Becht, M., Franks, J., Mayer, C., \& Rossi, S. (2009). Returns to shareholder activism: Evidence from a clinical study of the Hermes UK focus fund. Review of Financial Studies, 22(8), 3093-3129.

Bizjak, J., \& Marquette, C. (1998). Are shareholder proposals all bark and no bite? Evidence from shareholder resolutions to rescind poison pills. Journal of Financial and Quantitative Analysis, 33(4), 499-521.

Brav, A., Jiang, W., Partnoy, F., \& Thomas, R. (2008). Hedge fund activism, corporate governance, and firm performance. The Journal of Finance, 63(4), 1729-1775.

de Jong, A., Mertens, G., \& Roosenboom, P. (2006). Shareholders' voting at general meetings: Evidence from the Netherlands. Journal of Management and Governance, 10(4), 353-380.

Ertimur, Y., Ferri, F., \& Stubben, S. (2010). Board of directors' responsiveness to shareholders: Evidence from shareholder proposals. Journal of Corporate Finance, 16(1), 53-72.

Ferri, F., \& Sandino, T. (2009). The impact of shareholder activism on financial reporting and compensation: The case of employee stock options expensing. The Accounting Review, 84(2), 433-466.

Gillan, S., \& Starks, L. (2007). The evolution of shareholder activism in the United States. Journal of Applied Corporate Finance, 19(1), 55-73.

Gompers, P. A., Ishii, J. L., \& Metrick, A. (2003). Corporate governance and equity prices. Quarterly Journal of Economics, 118(1), 107-155.

ICGN (2009a) Global corporate governance principles: Revised (2009), International Corporate Governance Network, London.

ICGN (2009b) Second statement on the global financial crisis, International Corporate Governance Network, London.

Logsdon, J., \& Van Buren III, H. (2009). Beyond the proxy vote: Dialogues between shareholder activists and corporations. Journal of Business Ethics, 87(Supplement 1), 353-365.

Martin, K., \& Thomas, R. (1999). The effect of shareholder proposals on executive compensation. University of Cincinnati Law Review, 67, 1021-1081.

Melis A., Carta S., \& S. Gaia (2010), Executive Remuneration in Blockholder-dominated firms. How do Italian firms use stock options?, Dipartimento di Ricerche aziendali working paper.

Nesbitt, S. L. (1994). Long-term rewards from shareholder activism: A study of the "CalPERS Effect". Journal of Applied Corporate Finance, 6(4), 75-80.

(OECD) Principles of Corporate Governance (2004), Organisation for Economic Co-Operation and Development, Paris.

Thomas, R., \& Cotter, J. (2007). Shareholder proposals in the new millennium: Shareholder support, board response, and market reaction. Journal of Corporate Finance, 13(2-3), 368-391.

\section{Author Biographies}

Chris Mallin is Professor of Corporate Governance and Finance, and Director of the Centre for Corporate Governance Research, at Birmingham Business School, the University of Birmingham, UK. Her main research interests are corporate governance, particularly relating to institutional investors, and corporate social responsibility. She has published widely on corporate governance issues in academic and professional journals, including Journal of General Management, Journal of Business Finance and Accounting, European Journal of Finance, Applied Financial Economics, Multinational Finance Journal, Corporate Governance: An International Review, and the Journal of Business Ethics. The third edition of her book Corporate Governance was published by Oxford University Press in 2009.

Andrea Melis is Associate Professor of Accounting and Business Economics at the Department of Ricerche aziendali, University of Cagliari, Italy and member of the Centre for Corporate Governance Research, the University of Birmingham, UK. His main research interests are financial reporting, performance measurement and corporate governance. He has published three research monographs on corporate governance, several refereed book chapters and articles in international journals such as Accounting, Business and Financial History, Corporate Governance: An International Review, Corporate Ownership and Control, Journal of Management and Governance, and other premier accounting and business journals in Italy. 